\title{
ON THE USE OF THE SIMPLE SCALING OF HEAVY RAINFALL IN A REGIONAL ESTIMATION OF IDF CURVES IN SLOVAKIA
}

\author{
MÁRTA BARA, LADISLAV GAÁL, SILVIA KOHNOVÁ, \\ JÁN SZOLGAY, KAMILA HLAVČOVÁ
}

Department of Land and Water Resources Management, Faculty of Civil Engineering, Slovak University of Technology, Bratislava, Radlinského 11, 81368 Bratislava, Slovak Republic; Mailto: bara@svf.stuba.sk, ladislav.gaal@stuba.sk, silvia.kohnova@stuba.sk,jan.szolgay@stuba.sk,kamila.hlavcova@stuba.sk

The aim of this study was to test the applicability of a simple scaling methodology for a regional estimation of intensity-duration-frequency (IDF) curves in Slovakia. The analysis is based on the regionalization process of Gaál (2006), which focused on the delineation of homogeneous regions for a regional frequency analysis of precipitation maxima. In order to examine the regionally estimated IDF curves, a region covering the western parts of Slovakia was chosen. The selected region, which encompasses 19 raingauging stations, may be characterized by the dominant influence of Atlantic circulation patterns. Three of the 19 stations belonging to the target region were set aside and flagged as verification stations.

The regional dimensionless growth curve of 1-day precipitation maxima in the warm season was derived for the region, and the local T-year quantiles were estimated by the index value method for the stations. At the same time, a regionally averaged scaling exponent was derived using all the stations except for the three verification ones. The local IDF curves at the verification stations were estimated by downscaling the $T$ year quantiles of the 1-day precipitation maxima using the regionally averaged scaling exponent. Finally, the IDF curves for these stations were compared with those defined by $\breve{S} a m a j$, Valovič (1973). This study is the first step in assessing the applicability of a simple scaling theory for the regional estimation of IDF curves in Slovakia.

KEY WORDS: Regionalization, Rainfall Intensity, Simple Scaling, IDF Curves, Warm Season, 1-Day Maxima of Precipitation Totals.

Márta Bara, Ladislav Gaál, Silvia Kohnová, Ján Szolgay, Kamila Hlavčová: VYUŽITIE METÓDY JEDNODUCHÉHO ŠKÁLOVANIA EXTRÉMNYCH ZRÁŽOK PRI REGIONÁLNOM ODHADE NÁVRHOVÝCH DAŽĎOV NA SLOVENSKU. J. Hydrol. Hydromech., 58, 2010, 1; 44 lit., 8 obr., 5 tab.

Ciel'om tejto práce bolo otestovat' možnost' použitia metódy jednoduchého škálovania zrážok pri regionálnom odhade návrhových hodnôt zrážkových intenzít na Slovensku. Pre analýzu bolo vybraných 19 zrážkomerných staníc vo vopred vyčlenenom regióne na území západného Slovenska, pričom tri stanice boli separované ako verifikačné stanice. Pre vybraný región sme odvodili bezrozmernú regionálnu čiaru prekročenia jednodenných maximálnych úhrnov zrážok v teplom polroku a následne sme pre verifikačné stanice metódou indexovej hodnoty odhadli lokálne návrhové hodnoty pre rôzne významné doby opakovania $T$ (tzv. $T$-ročné kvantily). Vo vyčlenenom regióne sme určili priemerný regionálny škálovací koeficient. Návrhové zrážkové intenzity pre tri verifikačné stanice sa stanovili zoškálovaním $T$-ročných kvantilov jednodenných maximálnych zrážok pomocou regionálneho škálovacieho koeficientu. Určené návrhové hodnoty sme porovnali s výsledkami Šamaja, Valoviča (1973). Štúdia potvrdila možnost' využitia metódy jednoduchého škálovania na regionálny odhad návrhových hodnôt zrážkových intenzít na Slovensku.

KLÚČOVÉ SLOVÁ: regionalizácia, intenzita zrážok, jednoduché škálovanie, návrhové hodnoty, teplý polrok, jednodenné maximálne úhrny zrážok. 


\section{Introduction}

The relationship between the intensity, duration and frequency of rainfall (the IDF relationship) is one of the most commonly used tools in water resources engineering, either for the planning, design and operation of water resource projects or the protection of various engineering projects against floods. The establishment of such relationships goes back to the 1930s (Bernard, 1932). Since then, different forms of relationships have been constructed for several regions of the world. Since the 1960 s, the regional properties of IDF relationships have been studied in several countries, and maps have been constructed to provide the rainfall intensities or precipitation totals for various annual frequencies and durations. More recently, Koutsoyiannis et al. (1998) proposed a novel approach to the formulation and construction of IDF curves, which constitutes an efficient parameterization by facilitating the description of the geographical variability and rationalization of IDF curves and allowing for the incorporation of data from non-recording stations for constructing IDF curves at ungauged sites. Willems (2000) analyzed the IDF properties of extreme precipitation for two different storm types. He estimated different mixtures of these two types of storms both for summer and winter conditions, which brought new elements into the current understanding of what determines IDF curves and their scaling properties. Minh Nhat et al. (2007) developed a regional IDF relationship for ungauged locations based on the scaling theory. Acar et al. (2008) used a multilayer perceptron artificial neural network model to assess IDF relationships for short duration rainfalls.

The first attempts to construct regional IDF curves for Slovakia were made by $D u b$ (1950). Šamaj, Valovič (1973) presented a comprehensive IDF study based on 68 stations covering the area of Slovakia using data mostly from the period 1931-1960 . Their results were re-evaluated by Urcikán and Horváth (Urcikán, Imriška, 1986); however, the analysis mostly concentrated on different formal presentations of IDF curves. They also proposed a method for the spatial interpolation of IDF curves for sites with no direct observations.

In recent decades, hydrological research has devoted considerable attention to improving the representation of precipitation fields both in time and space. One of the most important issues recently is the development of various mono and multiscaling models. They recognize rainfall organization at different scales through the concept of mesoscale precipitation areas and the clustering of cells in space and time; see e.g. Waymire, Gupta (1981), Waymire et al. (1984), Rodriguez-Iturbe et al. (1984), Marien, Vandewiele (1986), Sivapalan, Wood (1987), Veneziano et al. (1996; 2007).

In recent years, many studies have been devoted to extreme rainfall and its scaling properties. Gupta, Waymire (1990) examined spatial rainfall by introducing the concepts of simple and multiple scaling to characterize the probabilistic structure of the precipitation process. Smith (1992) developed a multiscaling approach to characterize river flow distribution. Koutsoyiannis, Foufoula-Georgiu (1993) applied a scaling model to predict storm hyetographs. Bendjoudi et al. (1997) used the multifractal point of view on the IDF rainfall curves. Hubert et al. (2002) investigated the multi-fractal taming of extreme hydrometeorological events, which suggests that both rainfall and discharge extreme events might be ruled by statistical algebraic laws, rather than by exponential ones as has been generally postulated up to now. Rosso, Burlando (1990) adopted the concept of scale invariance to analyze some traditional forms of depthduration-frequency (DDF) relationships used in different countries to characterize extreme storm probabilities. The study showed that a synthesis of the regularities in a temporal storm pattern could characterize extreme storms better than traditional statistical techniques, which are usually carried out in order to identify and parametrize extreme storm probability distributions. A lognormal distribution model was also introduced to represent either simple or multiple scaling DDF curves from extreme value storm data (Burlando, Rosso, 1996). De Michele et al. (2002) developed intensity-durationarea frequency curves for the evaluation of design storms using a scaling approach. Nguyen et al. (1998) proposed a GEV distribution model for the regional estimation of short duration rainfall extremes based on a scaling theory. Javelle et al. (1999) investigated discharge-duration-frequency curve modeling for floods and scale invariance. Molnar, Burlando (2008) examined the variability of scaling exponents in a mountainous region. The study of Menabde et al. (1999) was devoted to a simple scaling hypothesis. It showed that based on the empirically observed scaling properties of rainfall and some general assumptions about the cumulative distribution function for the annual maxima of mean rainfall intensity, it is possible to derive a simple IDF relationship. $Y u$ et al. (2004) developed 
regional IDF formulas for non-recording sites based on a scaling theory. In general, a common feature of these studies is the hypothesis of scale invariance. The concept of scale invariance supposes that statistical moments of scale-invariant systems at different scales (i.e. larger or smaller temporal resolutions) are related by an operation (i.e. power law) that only involves the scale ratios. The practical potential of the scaling hypothesis lies in the fact that it allows for estimating design values of rainfall at selected recurrence intervals and durations shorter than a day by only using a simple powerlaw relationship in the combination with design values of daily precipitation data, which are available from a denser network of non-recording raingauges.

The motivation for this study was to verify the applicability of using a regionally averaged scaling exponent for the indirect estimation of IDF curves at sites with no rainfall observations. The core idea of the methodology was to select three verification stations, which, although being equipped with raingauges, were treated as ungauged sites. It was supposed that the only information on the precipitation regime at the verification stations was the index value, i.e., the average value of the at-site annual maxima of 1-day precipitation in the warm season (April-September). The rest of the characteristics (i.e., the quantiles of the regional growth curve and the scaling exponent, respectively) necessary for the simple scaling were estimated using regional approaches that relied on all but the three verification stations within the target region. Using the regional scaling exponent, the IDF curves were estimated by downscaling the design values of the 1-day precipitation maxima in the warm season. The IDF curves were finally compared with the IDF assessed by Šamaj, Valovič (1973).

The paper is organized as follows: Section 2 presents the methods used herein, including the regionalization procedure, the identification of the homogenous pilot region, and the estimation of the scaling exponent in the selected region. Section 3 describes the data used. The results of estimating the regional IDF curves in the three verification stations comparing them with the ones assessed by Šamaj, Valovič (1973) are presented in Section 4. Finally, the results are discussed and summarized in Section 5.

\section{Methodology}

In the following section, which summarizes the theoretical background of the current study, we deal with two main issues. The first one is the regional index value methodology (i.e., Hosking, Wallis, 1997), which is used to derive the $T$-year quantiles (i.e., the design values corresponding to the return period $T$, or annual frequency $P$, respectively) of the analyzed data set, namely the maxima of 1-day precipitation totals in the warm season. The second topic is the simple scaling methodology (i.e., $\mathrm{Me}$ nabde et al., 1999), which is employed to establish the IDF curves for the selected stations, i.e., based on the simple scaling relationship and the design values of the 1-day precipitation totals, it is used to assess the design values corresponding to shorter rainfall durations.

\subsection{Regional frequency analysis of 1-day precipitation maxima}

A regional precipitation frequency analysis of heavy precipitation in Slovakia has been carried out in Gaál (2006) according to the methodology proposed by Hosking, Wallis (1997), which is called the 'regional L-moment algorithm' and relies on four cornerstones:

- Screening of the data.

- Identification of homogeneous regions.

- Choice of a frequency distribution.

- Estimation of the regional frequency distribution, at-site quantiles and their confidence intervals.

\subsection{Screening of the data}

For the purposes of a frequency analysis, 56 climatological stations that more or less evenly cover the area of Slovakia have been selected from the database of the Slovak Hydrometeorological Institute (SHMI). The observation periods range from 1961 to 2003 at the majority of the stations; moreover, data from the period 1951-1960 that is available at some stations were also included in the basic data set. The shortest observation records are 35 years long (in 2 cases); on the other hand, the longest ones consist of 53 years (at 13 sites). The most common value of the record lengths is 43 years ( 15 occurrences).

The first step of the regional L-moment algorithm is aimed at identifying errors or inconsistencies in the data set to be processed, such as man- 
made mistakes, missing values, trends due to the climate change (e.g. Pekárová, 2009; Pekárová et al., 2008) or other inhomogenities. The basic screening of the data did not reveal any major inconsistencies; thus, we concluded that the collected data set of daily precipitation records is suitable for further climatological analyses (Gaál, 2006).

\subsection{Identification of homogeneous regions}

For our study, the regionalization of precipitation maxima derived by Gaál (2006) was used for the subsequent regional estimation of the design values of 1-day precipitation totals in the warm season. In this regionalization, the formation of homogeneous regions for regional precipitation frequency analysis in Slovakia was reached in three steps.

In the first step, cluster analysis was employed as an objective method of pooling. The discriminating variables were the geographical co-ordinates (latitude, longitude and altitude), the ratio of the precipitation totals for the warm and cold seasons, and Lapin's index of the Mediterranean effect (the latter characteristic is a descriptor of the intra-annual variability of monthly precipitation totals in Slovakia; see Gaál, 2005; Lapin, Melo, 2004, 2005; Cebulak et al., 2000). The result of the cluster analysis was the delineation of 5 homogeneous regions.

At the same time, a process-based (subjective) regionalization was carried out as the second step of the regionalization. The motivation for this idea was to take advantage of the knowledge of climatologists on the long-term precipitation regime of the country, which is influenced by the complex topography, the effects of different circulation patterns, and other mechanisms producing heavy precipitation. Following consultations with Faško (2006), four regions of extreme precipitation were identified.

The final set of homogeneous regions was created as a compromise between the results of the objective and subjective methods of regionalization, respectively. It is comprised of three regions: the western, the southern and the northern regions (Regions \#1, \#2 and \#3 on Fig. 1, respectively). Further considerations about how the regions were identified are given in Gaál (2006).

The regions were tested for regional homogeneity according to the Hosking, Wallis (1997) methodology. The Hosking and Wallis heterogeneity measure $H$ is a quantification of a simulation procedure where the actual variability of the second moments within the given region is compared with the variability of the second moments within a homogeneous region (i.e. in a region with no inter-site correlations). The critical $H$ values are set as follows: the region is acceptably homogeneous if $H<$ 1 , possibly heterogeneous if $1 \leq H<2$, and definitely heterogeneous if $H \geq 2$ (Hosking, Wallis, 1997).

The heterogeneity measure $H$ for the maxima of the daily precipitation totals in the warm season reached the following values: 0.28 in Region $\# 1$; -0.32 in Region \#2 and 1.23 in Region \#3. All of these results indicate an acceptable degree of the regional homogeneity of the regions.

Out of the final three regions, Region \#1, comprising the western parts of Slovakia and characterized by the dominant influence of Atlantic circulation patterns (mostly in its northern parts), was selected for the aims of the current study.

\subsection{Choice of a frequency distribution}

The Z-test by Hosking, Wallis (1997) was applied to select an appropriate regional frequency distribution. According to the recommendations of Hosking, Wallis (1997), the goodness-of-fit of the following 3-parameter distribution functions has been tested: GEV (generalized extreme value), GLO (generalized logistic), GNO (generalized normal) and PE3 (Pearson type III).

Generally, the goodness-of-fit of the proposed distribution functions for precipitation maxima in the warm season (Gaál, 2006) showed that the GEV was a suitable regional distribution function and was used for the regional estimation of the design precipitation totals in our study.

\subsection{Simple scaling of rainfall}

In this study, a simple scaling hypothesis was adopted in order to derive the intensity-durationfrequency (IDF) characteristics of the rainfall. The methodology applied herein follows the one used in Menabde et al. (1999) and $Y u$ et al. (2004). A complete overview is not presented; only the main principles are outlined. For detailed information on the theoretical background on the multifractal behavior of rainfall, the reader is referred to Veneziano, Furcolo (2002), and Lovejoy, Schertzer (1985); more practice-oriented results can be found, e.g., in Gupta, Waymire (1990), Menabde et al. (1999), Yu et al. (2004) and Molnar, Burlando (2008).

Let $I_{d}$ and $I_{\lambda d}$ denote the annual maximum rainfall intensity series for the time durations $d$ and $\lambda d$, 


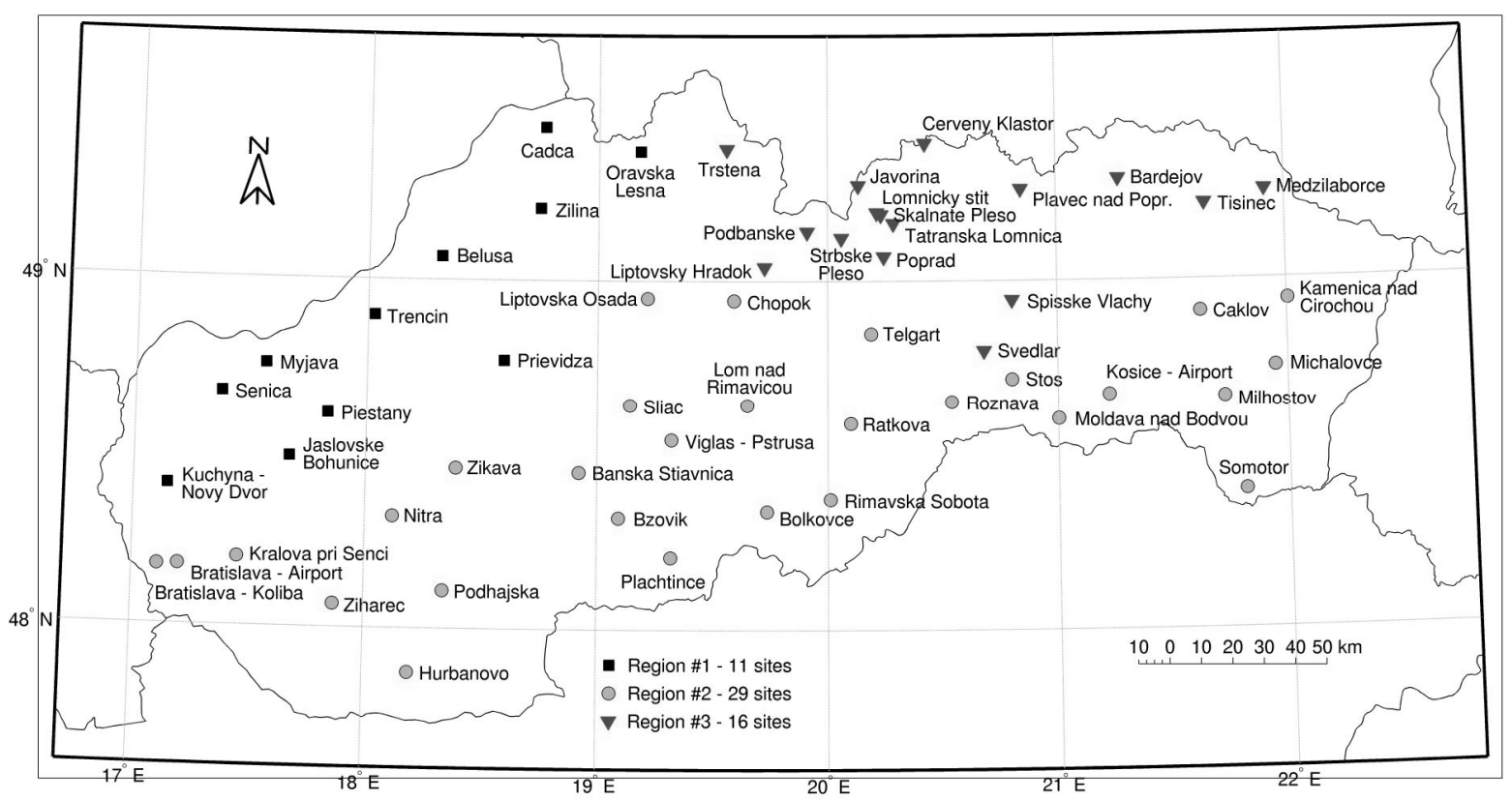

Fig. 1. A sketch of the location and composition of the homogeneous regions of maximum daily precipitation totals in the warm season.

Obr. 1. Náčrt lokalizácie a zloženia homogénnych regiónov maximálnych denných úhrnov zrážok v teplom polroku.

respectively. The two random variables $I_{d}$ and $I_{\lambda d}$ are related through the scale factor $\lambda$ (which is the ratio between the two time durations) and have the same scaling property as ( $Y u$ et al., 2004):

$I_{\lambda d} \stackrel{\text { dist }}{=} \lambda^{\beta} I_{d}$

where the equality is meant in the sense of the equality of the probability distributions of both variables, and $\beta$ represents the scaling exponent. Such a behaviour is denoted as 'simple scaling in the strict sense' (Gupta, Waymire, 1990).

This type of scaling implies that both variables have the same probability distribution function if the finite moments of an order $q$ exist for both. The relationship between the $q^{\text {th }}$ moments of rainfall intensity can be obtained after raising both sides of Eq. (1) to power $q$ and taking the ensembles' average ( $Y u$ et al., 2004):

$E\left[I_{\lambda d}^{q}\right]=\lambda^{\beta q} E\left[I_{d}^{q}\right]$

where $\beta_{q}$ represents the scaling exponent of order $q$. The scaling exponent can be estimated from the slope of the linear regression relationships between the log-transformed values of the moments and the scale exponents for the various orders of moments. The case where the relationship between the scaling exponent and order of moment is linear is referred to as 'wide sense simple scaling' (Gupta, Waymire, 1990).

The scaling behavior can also be found for the parameters of a fitted cumulative distribution function (CDF) if the CDF has a standardized form (Menabde et al., 1999; Yu et al., 2004)

$F_{d}(i)=F\left(\frac{i-\mu_{d}}{\sigma_{d}}\right)$,

where function $F$ is independent of $d$. For the simple scaling process it can be shown that the statistical properties of the CDF for the two different timescales $d$ and $\lambda d$ are related as follows (Menabde et al., 1999; $Y u$ et al., 2004):

$\mu_{\lambda d}=\lambda^{\beta} \mu_{d}$

and

$\sigma_{\lambda d}=\lambda^{\beta} \sigma_{d}$,

where $\mu_{d}\left(\sigma_{d}\right)$ is the location (scale) parameter of the annual precipitation maxima of duration $d, \lambda$ denotes a scale factor, and $\beta$ - the scaling exponent. Based on these assumptions, the intensities $I_{d}^{P}$ of events with the same annual frequency $P$, but a different duration $d$, will satisfy the scaling relation

$I_{\lambda d}^{P}=\lambda^{\beta} I_{d}^{P}$. 
On the basis of Eq. (6), it is possible to estimate the scaling exponent even if the data record is short (Menabde, 1999).

\section{Data analysis}

Based on the regionalization of the 1-day precipitation maxima in the warm season by Gaál (2006, Fig. 1), the western region of Slovakia was selected for our study. The target region has no firmly determined boundaries; however, we selected 19 raingauge stations (Tab. 1), which are thought to fit in this region from a climatological point of view. (Note that the stations depicted in Fig. 1 were used in the regionalization process and are not necessarily identical to the selection in Tab. 1).

The primary data set of raingauge stations analyzed, which consisted of rainfall intensities with a given annual frequency, was extracted by the peak- over-threshold approach from records of automated raingauges (for details, see Šamaj, Valovič, 1973). The derived dataset consists of the quantiles of rainfall intensities of durations from 5 up to 180 minutes as estimated empirically by Šamaj, Valovič (1973). The historical quantile data were checked and preprocessed according to a methodology described in detail in Bara et al. (2008) and Bara (2008). The daily rainfall amounts, which were taken from the archive of the SHMI, were not corrected for sliding duration (see, e.g., FEH, 1999). The quantiles of the 1-day (1440 $\mathrm{min})$ precipitation duration for different annual frequencies were estimated using the GEV distribution function.

The periods of observation and the number of years observed for each station are summarized in Tab. 1. Generally, the periods of observation range from the 1930s to the 1960s, and the average length of observation is approximately 17 years.

$\mathrm{T}$ a b $1 \mathrm{e}$ 1. List of the raingauge stations (with record lengths and exact years of observations) used in the rainfall scaling procedure.

$\mathrm{T}$ a b u l' k a 1. Zoznam analyzovaných ombrografických staníc (počet rokov pozorovania a pozorované obdobia) použitých pri škálovaní zrážok.

\begin{tabular}{lcl}
\hline Station & Record length & \multicolumn{1}{c}{ Observation period } \\
\hline Čadca & 17 & $1949-1965$ \\
Holíč & 18 & $1946-1949,1951-1961,1963-1965$ \\
Ilava & 22 & $1944-1965$ \\
Kšinná & 12 & $1931-1940,1943-1944$ \\
Kuchyňa Nový Dvor & 21 & $1934-1937,1946-1949,1951-1955,1958-1965$ \\
Malé Bielice & 13 & $1948-1949,1955-1965$ \\
Modra-Pánsky dom & 20 & $1925-1939,1941-1944,1946$ \\
Motešice-Letný dvor & 14 & $1931-1944$ \\
Nitrianske Pravno & 17 & $1925-1941$ \\
Oravská Lesná & 16 & $1944,1946-1949,1952-1954,1956-1957,1960-1965$ \\
Oravský Podzámok & 14 & $1944-1948,1951,1953,1955,1957-1962$ \\
Oravská Polhora & 23 & $1930-1952$ \\
Piešt’any & 13 & $1949,1951-1959,1963-1965$ \\
Prievidza & 14 & $1951-1961,1963-1965$ \\
Trenčianske Biskupice & 12 & $1940-1943,1946-1952,1955$ \\
Trnava & 22 & $1930-1952$ \\
Valašská Belá & 16 & $1949,1951-1965$ \\
Vel'ké Rovné-Podivor & 27 & $1935-1938,1940-1944,1946-1953,1956-1965$ \\
Žilina & 19 & $1946-1949,1951-1965$ \\
\hline
\end{tabular}

Three stations from the target region were flagged as verification stations: Kuchyňa-Nový Dvor, Nitrianske Pravno and Čadca. The stations were selected according to the following three options: i) they characterize different geographical locations in the target region; ii) they represent the mean, minimum and maximum value of the scaling exponents in the analyzed region, and iii) they have their counterparts in the set of stations that were used in the delineation of the target region. The latter option needs some further explanation. As mentioned above, two sets of stations are used in 
this analysis: the first group (11 stations, nonautomated raingauges) formerly used in the regionalization process and the second group (19 stations, automated raingauges) used in the scaling process. The two groups of sites are also different from the aspect of their observation periods. Nonetheless, there are several sites that are identical in both groups (Čadca and Kuchyňa-Nový Dvor), or, with a certain degree of approximation, can be considered as identical (Nitrianske Pravno and Prividza, at a distance of $10 \mathrm{~km}$ from each other). Consequently, any regional estimation (see Sect. 4) is based on all the sites within the individual groups of sites except for the three verification stations, i.e., based on the remaining 8 non-automated raingauges and the 16 automated raingauges, respectively.

The station of Kuchyňa-Nový Dvor is situated in the southern part of the region, at an altitude of 206 $\mathrm{m}$ a.s.l., with a record length of 21 years. The Nitrianske Pravno station is located in the centre of the region, at an altitude of $351 \mathrm{~m}$ a.s.l. The period of observation available at this station is 17 years.
The Čadca station is found in the northern part of Western Slovakia, at an altitude of $423 \mathrm{~m}$ a.s.l.; the record length used in the analysis is 17 years.

Fig. 2 shows the relationships between the logtransformed values of moments of rainfall unit yields of various orders against various rainfall durations at the Čadca station, which is one of the verification stations.

The displayed data set consists of rainfall unit yields of duration from 5 up to 180 minutes evaluated empirically by Šamaj, Valovič (1973), extended by the estimated daily rainfall amounts using the GEV distribution. The return periods in the historical dataset were adjusted from empirical POT annual frequencies to the annual maximum return periods by the Langbein formula (Langbein, 1949; Szolgay et al., 2007). Despite the slight inconsistency in the method for the derivation of both datasets, it can be seen that the newly-added daily data are consistent with the tendency of the historical dataset. This implies the existence of scaling behavior in the data.

\section{Čadca}

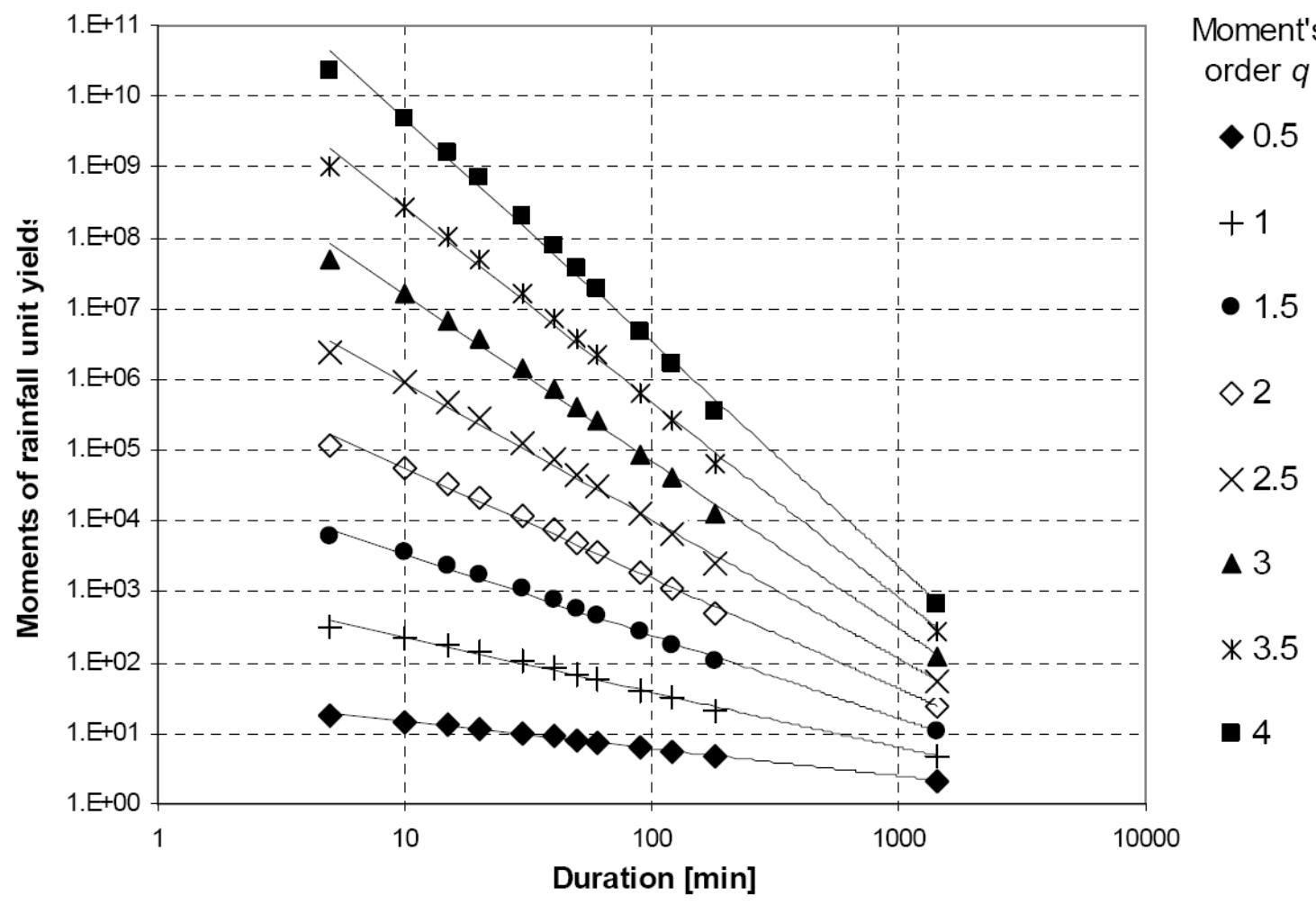

Fig. 2. The relationships between the log-transformed values of moments of various orders against various rainfall durations at the Čadca station - scaling of the moments of rainfall unit yields.

Obr. 2. Vzt’ah medzi momentmi špecifických výdatností zrážok a trvaním zrážok v stanici Čadca - škálovanie momentov špecifických výdatností zrážok. 


\section{Results}

First, the quantiles of the dimensionless regional frequency distribution GEV were derived for the selected region, using the 1-day precipitation maxima in the warm season. Tab. 2 shows the values of the estimated quantiles of the dimensionless regional frequency distribution for different annual frequencies.

$\mathrm{T}$ a b l e 2. Quantiles of the dimensionless regional frequency distribution, derived according to the GEV distribution function.

$\mathrm{T}$ a b u l'k a 2. Kvantily bezrozmernej regionálnej čiary prekročenia, získané na základe teoretického rozdelenia pravdepodobnosti GEV.

\begin{tabular}{lcccccc}
\hline Annual frequency & 0.5 & 0.2 & 0.1 & 0.05 & 0.02 & 0.01 \\
\hline Quantile estimates & 1.019 & 1.2695 & 1.4672 & 1.6722 & 1.9553 & 2.1769 \\
\hline
\end{tabular}

The design values of the 1-day precipitation maxima in the warm season were estimated for the three verification stations using the quantiles in Tab. 2, according to the index value methodology (Hosking, Wallis, 1997). As the index value, the mean of the warm season precipitation maxima was used, which was estimated using the at-site records of the 1-day precipitation maxima. Subsequently, the design values of the 1-day precipitation were transformed into rainfall intensities $\left[1 \mathrm{~s}^{-1} \mathrm{ha}^{-1}\right]$.

Using the simple scaling methodology, the design values of the rainfall of selected recurrence intervals and durations shorter than a day were estimated by downscaling the design values of the 1day precipitation. For the downscaling, the average scaling exponent estimated for the selected region (again, with the verification stations excluded), whose value was 0.7321 , was used, and the design values of the rainfall for the durations of $5,10,15$, $20,30,40,50,60,90,120$ and 180 minutes were derived. In the analysed region the scaling exponents vary from 0.6700 to 0.8069 , the standard error of the mean is 0.002418 .

\section{Kuchyňa - Nový Dvor}
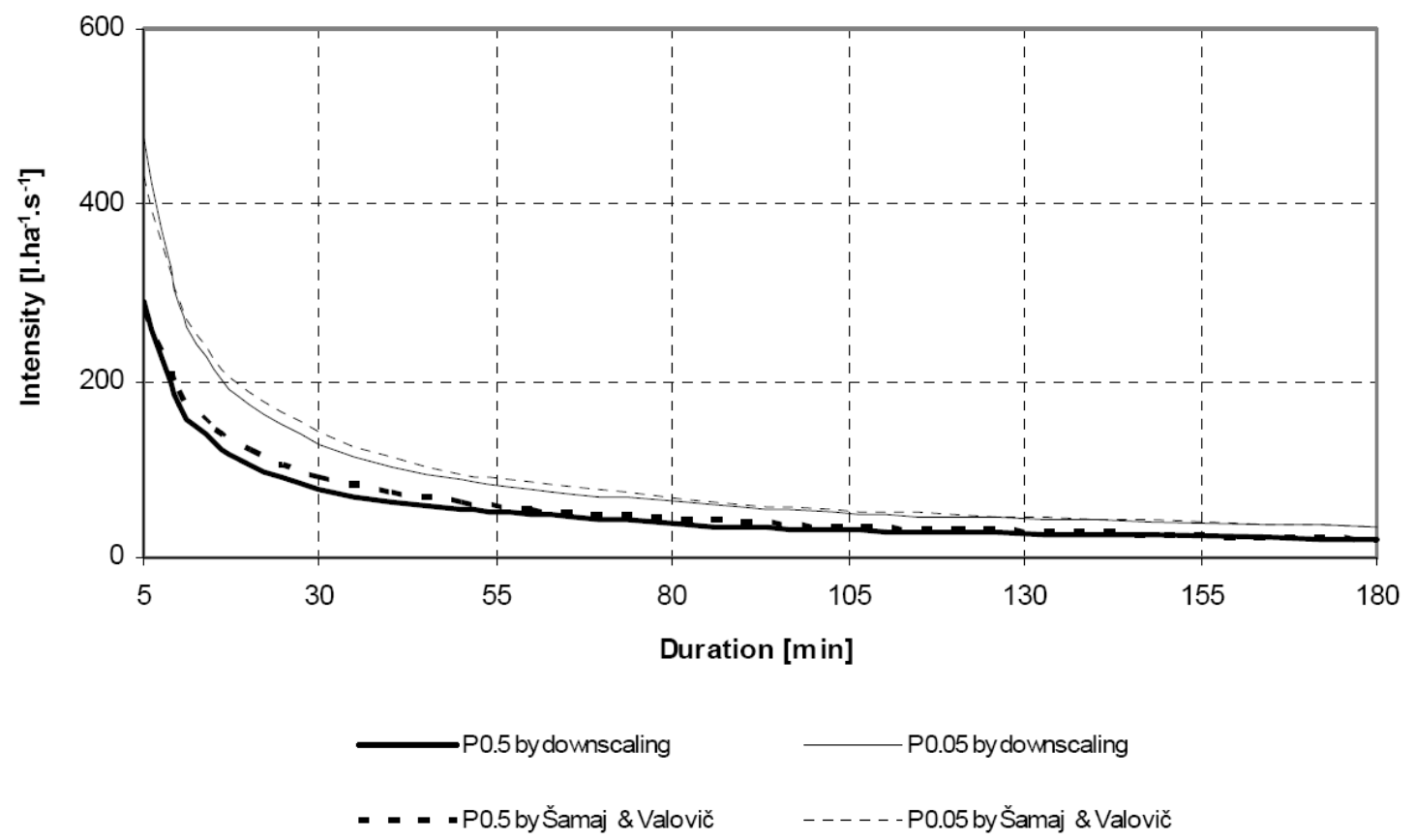

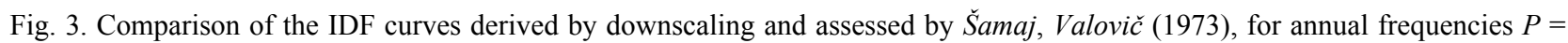
$=0.5$ and 0.05 at the Kuchyňa-Nový Dvor station.

Obr. 3. Porovnanie čiar intenzít náhradných dažd’ov určených škálovaním a autormi Šamaj, Valovič (1973) pre periodicity $P=0,5$ a 0,05, stanica Kuchyňa-Nový Dvor. 


\section{Nitrianske Pravno}
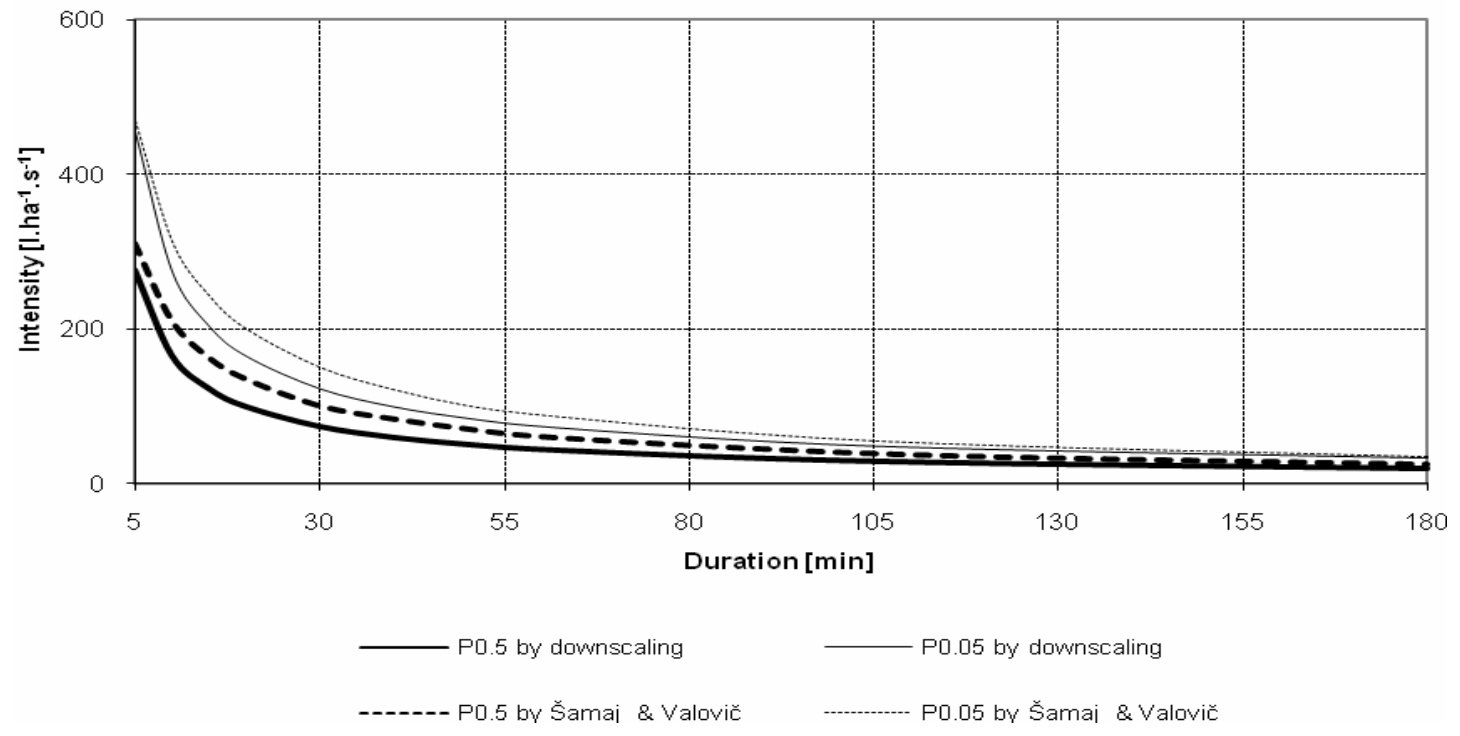

Fig. 4. Comparison of the IDF curves derived by downscaling and assessed by Šamaj, Valovič (1973) for annual frequencies $P=$ $=0.5$ and 0.05 at the Nitrianske Pravno station.

Obr. 4. Porovnanie čiar intenzít náhradných dažd’ov určených škálovaním a autormi Šamaj, Valovič (1973) pre periodicity $P=0,5$ a 0,05 , stanica Nitrianske Pravno.

\section{Čadca}

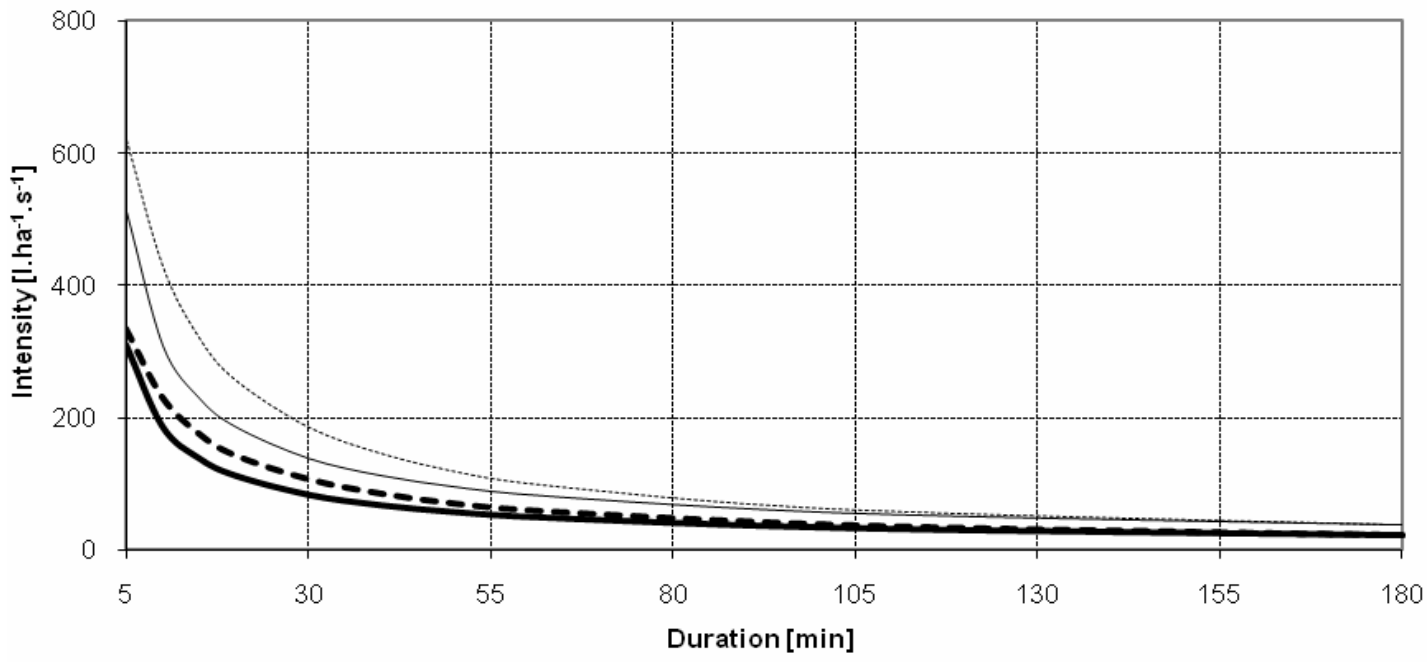

P0.5 by downscaling

P0.5 by Šamai \& Valovič
P0.05 by downscaling

P0.05 by Šamai \& Valovič

Fig. 5. Comparison of the IDF curves derived by downscaling and assessed by Šamaj, Valovič (1973) for annual frequencies $P=$ $=0.5$ and 0.05 at the Čadca station.

Obr. 5. Porovnanie čiar intenzít náhradných dažd’ov určených škálovaním a autormi Šamaj, Valovič (1973) pre periodicity $P=0,5$ a 0,05 , stanica Čadca. 
The dependence of the scaling exponents on selected geographical and climatological characteristics was also examined. The following site attributes were considered:

- elevation above the sea level [m],

- mean annual precipitation [mm],

- Lapin's index of the Mediterranean effect [-],

- maximum air temperature in the warm season $\left[{ }^{\circ} \mathrm{C}\right]$,

- mean annual number of stormy days [-],

- 100-year quantile of the annual maxima of 1-day precipitation totals $[\mathrm{mm}]$, and

- 50-year quantile of the annual maxima of 1-day precipitation totals $[\mathrm{mm}]$.

Nevertheless, the squared correlation coefficient $r^{2}$ revealed no linear relationship between $\beta$ and the selected site attributes.

Figs. 3-5 show a comparison of the regionally estimated IDF curves in the three verification stations selected with the IDF by Šamaj, Valovič (1973). Generally, for all the durations, a systematic underestimation of the IDF curve values estimated by the regional approach can be distin- guished. To compare the IDF curve values, the relative differences $(R D)$ were calculated using the formula:

$R D=\frac{X-Y}{Y} 100 \quad[\%]$,

where $X$ are the design rainfall values determined by downscaling and $Y$ - the design values assessed by Šamaj, Valovič (1973). The results of this comparison are listed in Tabs. 3-5. Only annual frequencies which overlapped with the annual frequencies of those estimated by Šamaj, Valovič (1973) were compared.

From the results in Tabs. $3-5$, it is obvious that for a duration longer than 10 minutes and for all annual frequencies, the regionally derived values of the relative differences [\%] between the design rainfall intensities estimated by simple scaling are lower compared to the IDFs by Šmaj, Valovič (1973). The differences rise up to about $29 \%$ (in an absolute sense) for the verification stations, and the average is about $15 \%$.

$\mathrm{T}$ a b $1 \mathrm{e} 3$. The relative differences [\%] between the design rainfall intensities estimated by simple scaling and the design values derived by Šamaj, Valovič (1973) at the Kuchyňa-Nový Dvor station.

T a b u l'k a 3. Relatívna odchýlka [\%] medzi návrhovými hodnotami určenými metódou jednoduchého škálovania a návrhovými hodnotami stanovenými Šamajom, Valovičom (1973), stanica Kuchyňa-Nový Dvor.

\begin{tabular}{cccccccccccc}
\hline \multicolumn{10}{c}{ Kuchyňa - Nový Dvor } \\
$\begin{array}{c}\text { Annual } \\
\text { frequency }\end{array}$ & 5 & 10 & 15 & 20 & 30 & 40 & 50 & 60 & 90 & 120 & 180 \\
\hline 0.5 & 3.4 & -7.3 & -11.3 & -13.3 & -14.3 & -14.6 & -13.5 & -13.1 & -12.8 & -8.8 & 0.0 \\
0.2 & 6.1 & -6.4 & -9.8 & -12.3 & -13.3 & -12.6 & -12.1 & -12.7 & -7.5 & -4.8 & 4.7 \\
0.1 & 8.3 & -4.6 & -8.1 & -10.1 & -11.6 & -11.7 & -10.2 & -9.9 & -7.0 & -3.1 & 4.3 \\
0.05 & 10.0 & -2.0 & -5.9 & -7.9 & -9.2 & -9.1 & -7.3 & -8.3 & -4.6 & -1.3 & 4.5 \\
\hline
\end{tabular}

$\mathrm{T}$ a b $1 \mathrm{e}$ 4. The relative differences [\%] between the design rainfall intensities estimated by simple scaling and the design values derived by Šamaj, Valovič (1973) at the Nitrianske Pravno station.

T a b u l'k a 4. Relatívna odchýlka [\%] medzi návrhovými hodnotami určenými metódou jednoduchého škálovania a návrhovými hodnotami stanovenými Šamajom, Valovičom (1973), stanica Nitrianske Pravno.

Nitrianske Pravno

\begin{tabular}{cccccccccccc}
\hline $\begin{array}{c}\text { Annual } \\
\text { frequency }\end{array}$ & 5 & 10 & 15 & 20 & 30 & 40 & 50 & 60 & 90 & 120 & 180 \\
\hline 0.5 & -11.0 & -21.0 & -24.0 & -25.7 & -25.4 & -27.2 & -26.7 & -25.2 & -24.2 & -20.5 & -16.3 \\
0.2 & -9.7 & -18.2 & -22.0 & -23.3 & -23.8 & -23.2 & -23.0 & -22.3 & -20.0 & -15.8 & -10.6 \\
0.1 & -7.3 & -16.1 & -19.3 & -20.6 & -21.6 & -21.6 & -19.7 & -19.2 & -15.7 & -13.5 & -6.7 \\
0.05 & -3.3 & -12.6 & -16.3 & -17.6 & -18.4 & -18.0 & -15.8 & -16.3 & -13.1 & -9.5 & -3.0 \\
\hline
\end{tabular}


$\mathrm{T}$ a b 1 e 5 . The relative differences [\%] between the design rainfall intensities estimated by simple scaling and the design values derived by Šamaj, Valovič (1973) at the Čadca station.

T a b u l'k a 5. Relatívna odchýlka [\%] medzi návrhovými hodnotami určenými metódou jednoduchého škálovania a návrhovými hodnotami stanovenými Šamajom, Valovičom (1973), stanica Čadca.

Čadca

\begin{tabular}{cccccccccccc}
\hline Annual & \multicolumn{10}{c}{ Duration of rainfall unit yields [min] } \\
frequency & 5 & 10 & 15 & 20 & 30 & 40 & 50 & 60 & 90 & 120 & 180 \\
\hline 0.5 & -7.0 & -18.8 & -20.8 & -21.1 & -21.6 & -20.1 & -17.6 & -15.8 & -12.7 & -7.9 & 2.7 \\
0.2 & -11.4 & -23.4 & -24.9 & -25.6 & -24.8 & -23.0 & -21.0 & -19.3 & -15.0 & -9.8 & 0.5 \\
0.1 & -17.3 & -26.8 & -27.8 & -27.4 & -25.9 & -24.7 & -21.6 & -19.2 & -15.6 & -10.7 & -1.4 \\
0.05 & -17.6 & -28.1 & -28.5 & -27.6 & -25.6 & -23.1 & -19.7 & -17.1 & -10.7 & -7.6 & 0.2 \\
\hline
\end{tabular}

Finally, for the three verification stations, the IDF curve values were determined using the locally estimated design values of 1-day maxima in a combination with the regionally estimated scaling exponent of the rainfall. The comparison of the design rainfall of the sub-daily duration for the annual frequency $P=0.05$ and assessed by the three different estimation approaches at the three verification stations are shown in Figs. 6-8.

The results presented indicate that the values of the design rainfall estimated by downscaling the regional or at-site design values of the 1-day precipitation maxima are underestimated by $15 \%$ on average in comparison with the values derived by Šamaj, Valovič (1973). The largest differences are observed for the shorter rainfall durations, while the results of all the methods tested are very similar up to the durations of about 60 minutes.

The comparison of the downscaled design rainfall, based either on the regional or the at-site estimates of the design values of the 1-day precipitation maxima, reveals that the regionally estimated values can be lower (Nitrianske Pravno) as well as higher (Čadca) than the at-site estimates. This is mainly caused by the smoothing effect of the regional approach to the estimation of the 1-day quantiles. At the Kuchyňa-Nový Dvor station, the at-site and the regional estimates of 1-day design precipitation were very similar, which resulted in the very close design values of the IDF curves.

On the example of the selected verification stations a consistent underestimation of the rainfall intensity quantiles (mostly for shorter durations) can be discerned. One of the possible explanations of this feature might be that the simple scaling hypothesis is not ideal. For instance, several studies (Marani, 2005; and references therein) argue that although the simple scaling holds for a range of temporal scales, a cut-off in the expected behaviour of the IDF curves is observed about the durations of 40
-60 minutes. To overcome this deficiency, the adoption of the multiscaling hypothesis is advised.

It is likely that the Slovak case fits in the framework of the aforementioned studies; however, a further examination (verification of the simple scaling behaviour at a higher number of stations) is necessary to derive more general conclusions. Moreover, it is anticipated that an ongoing statistical analysis of the available records of the limited number automated raingauges in Slovakia will provide further useful information on the scaling properties of the extreme rainfall of sub-daily durations.

\section{Conclusions}

The aim of this study was to test the applicability of simple scaling for the regional estimation of intensity-duration-frequency (IDF) curves in Slovakia. Out of the 19 stations belonging to the selected region, three were treated as verification stations. The regional dimensionless growth curve of the 1-day precipitation maxima in the warm season was derived in the region, and the regionally averaged scaling exponent was derived using all the stations except for the three verification ones. The local IDF curves at the verification stations were estimated by downscaling the quantiles of the 1-day precipitation maxima estimated regionally and locally, respectively, and by using the regionally averaged scaling exponent. From the results it is notable, that the values of the design rainfall estimated by downscaling the regional or at-site design values of the 1-day precipitation maxima are underestimated by $15 \%$ on average with a comparison of the values derived by Šamaj, Valovič (1973).

This study was the first step in assessing the applicability of the simple scaling theory by the regional estimation of IDF curves in Slovakia. 


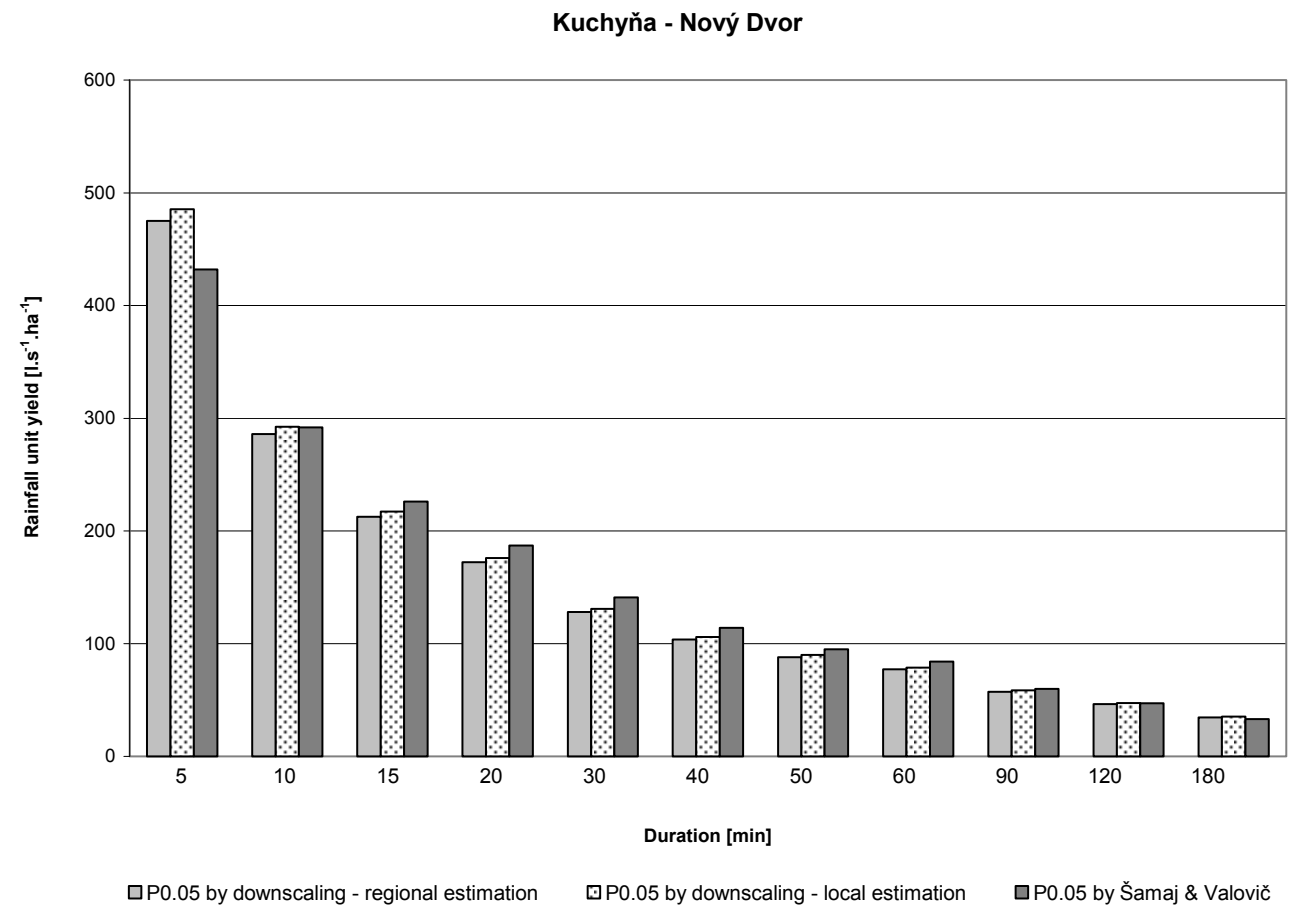

Fig. 6. Comparison of the design rainfall values for the annual frequency $P=0.05$ estimated by three different approaches at the Kuchyňa-Nový Dvor station.

Obr. 6. Porovnanie návrhových hodnôt pre periodicitu $P=0,05$ určených tromi rôznymi prístupmi, stanica Kuchyňa-Nový Dvor.

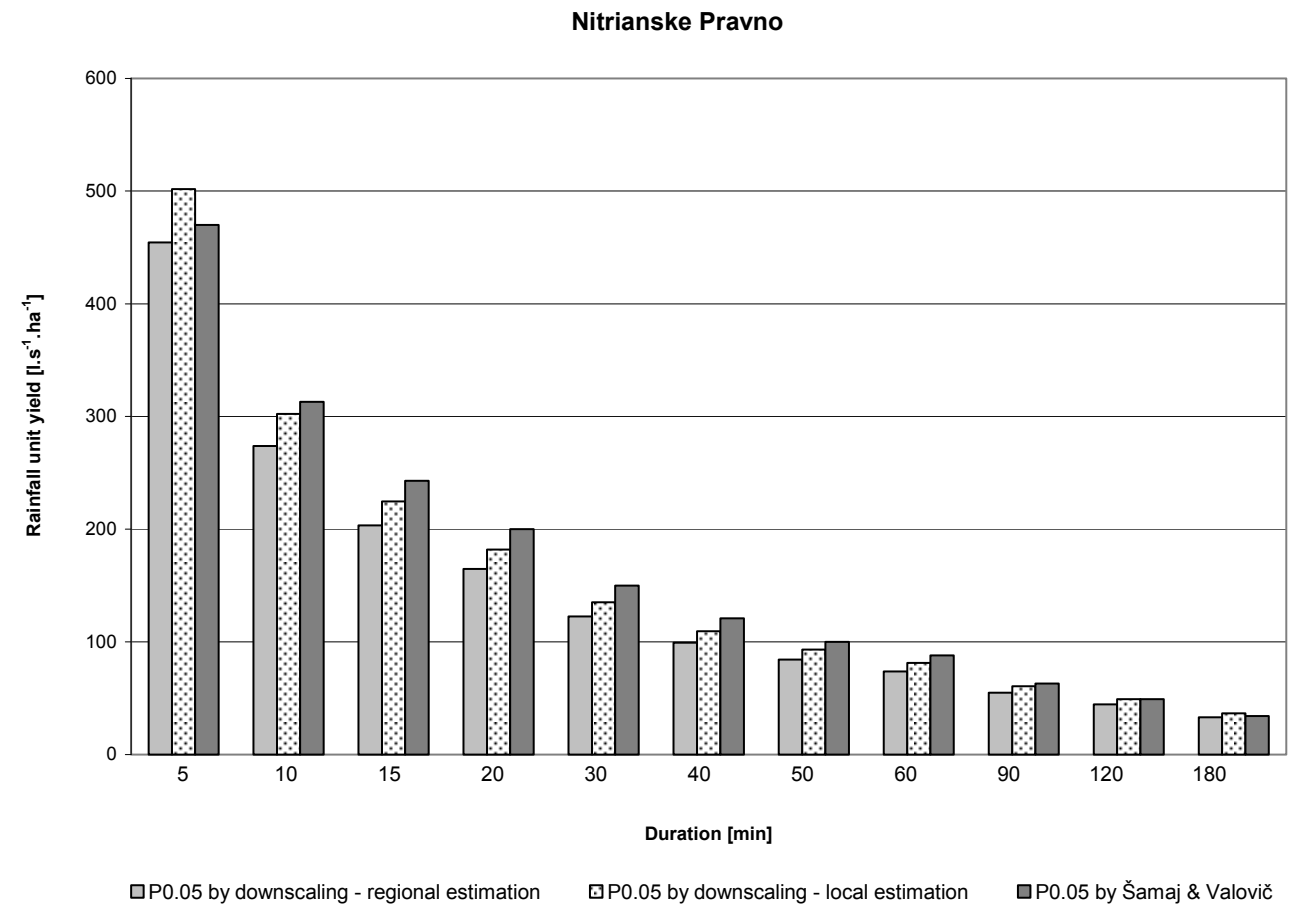

Fig. 7. Comparison of the design rainfall values for the annual frequency $P=0.05$ estimated by three different approaches at the Nitrianske Pravno station.

Obr. 7. Porovnanie návrhových hodnôt pre periodicitu $P=0,05$ určených tromi rôznymi prístupmi, stanica Nitrianske Pravno. 


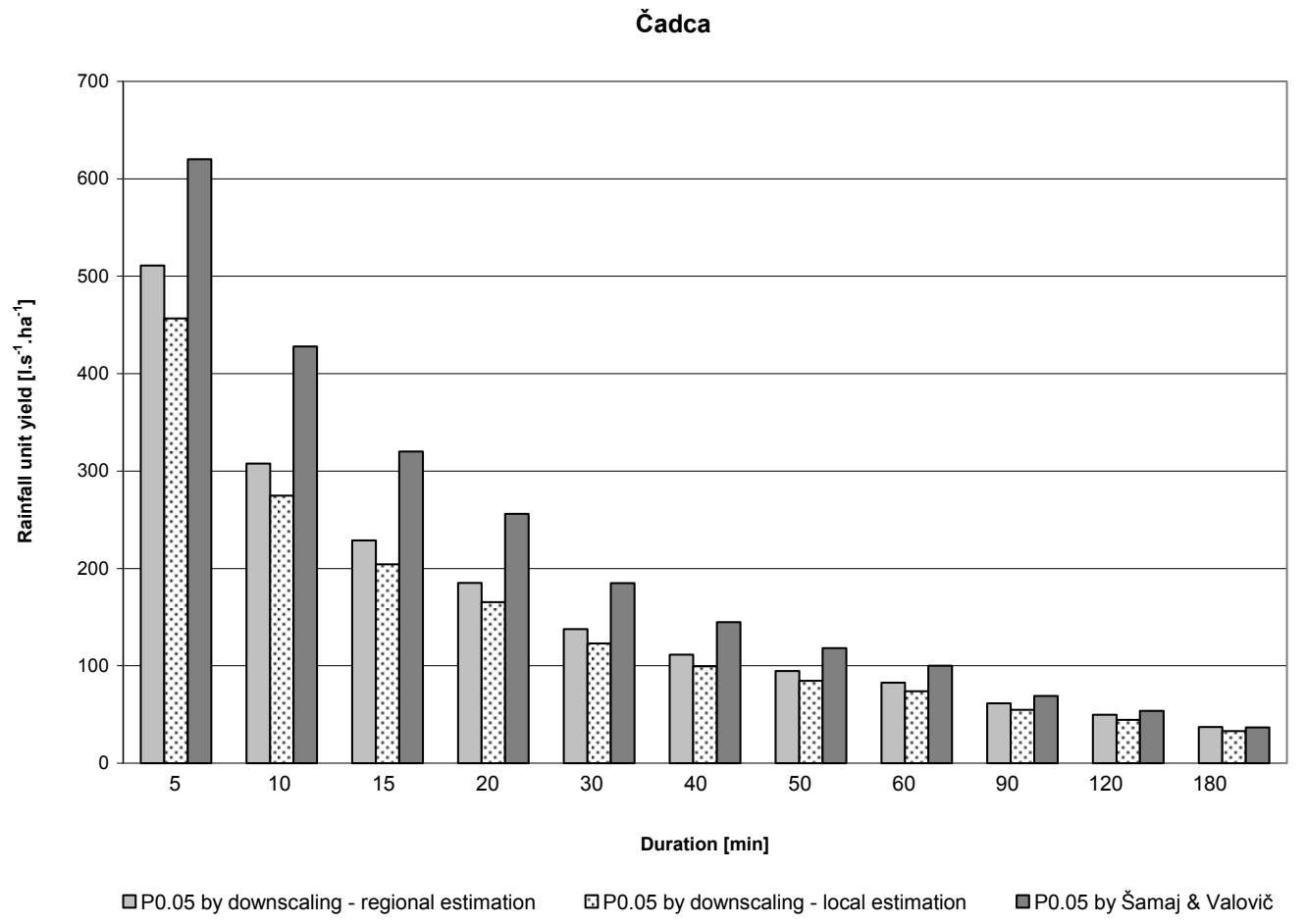

Fig. 8. Comparison of the design rainfall values for the annual frequency $P=0.05$ estimated by three different approaches at the Cadca station.

Obr. 8. Porovnanie návrhových hodnôt pre periodicitu $P=0,05$ určených tromi rôznymi prístupmi, stanica Čadca.

Acknowledgement. This work was supported by the Slovak Research and Development Agency under the contract No. APVV-0443-07 and under the VEGA Project No. 1/0496/08. This support is gratefully acknowledged.

\section{REFERENCES}

ACAR R., CELIK S., SENOCAK S., 2008: Rainfall intensityduration-frequency model using an artifical neural network approach. Journal of Scientific and Industrial Research, 67, 198-202.

BARA M., 2008: Analýza intenzít krátkodobých dažd’ov na Slovensku. (Analysis of short-time rainfall intensities in Slovakia.) (In Slovak.) [Written project of the PhD. thesis.] Department of Land and Water Resources Management, Faculty of Civil Engineering, Slovak University of Technology, Bratislava, $52 \mathrm{pp}$.

BARA M., GAÁL L., KOHNOVÁ S., SZOLGAY J., HLAVČOVÁ K., 2008: Simple scaling of extreme rainfall in Slovakia: a case study. Meteorological Journal, 11, 4, 153-157.

BENDJOUDI H., HUBERT P., SCHERTZER D., LOVEJOY S., 1997: Multifractal point of view on rainfall intensityduration-frequency curves. C. R. Acad. Sci. Paris, Earth and Planetary Sciences, 325, 323-326.

BERNARD M.M., 1932: Formulas for rainfall intensities of long durations. Trans. ASCE, 96, 592-624.

BURLANDO P., ROSSO R., 1996: Scaling and multiscaling models of depth-duration-frequency curves for storm precipitation. Journal of Hydrology, 187, 45-65.
CEBULAK E., FAŠKO P., LAPIN M., ŠŤASTNÝ P., 2000: Extreme precipitation events in the Western Carpathians. In: Images of Weather and Climate. Prace Geograficzne, fasc. 108. Institute of Geography of the Jagellonian University, Cracow, 117-124.

DE MICHELE C., KOTTEGODA N.T., ROSSO R., 2002: IDAF (intensity-duration-area-frequency) curves of extreme storm rainfall: a scaling approach. Water Science and Technology, 25, 2, 83-90.

DUB O., 1950: Hydrologické podklady pre výpočet kanalizačných sietí. (Hydrological inputs for sewage system design.) (In Slovak.) Voda, 5-6.

FAŠKO P., 2006: Slovak Hydrometeorological Institute. March, 2006. Personal communication, pavol.fasko@ shmu.sk.

FEH, 1999: Flood Estimation Handbook, Volume 2: Rainfall frequency estimation. Institute of Hydrology.

GAÁL L., 2005: Introduction of Lapin's indices into the cluster analysis of maximum k-day precipitation totals in Slovakia. Meteorological Journal, 8, 2, 85-94.

GAÁL L., 2006: Metódy výpočtu štatistických charakteristík návrhových hodnôt krátkodobých až viacdenných úhrnov zrážok. (Estimation methods of statistical properties of short-term to several-day design precipitation in Slovakia.) (In Slovak.) [PhD. thesis.] Faculty of Mathematics, Physics and Informatics, Comenius University in Bratislava,. $228 \mathrm{pp}$.

GUPTA V.K., WAYMIRE E., 1990: Multiscaling properties of spatial and river flow distributions. Journal of Geophysical Research, 95, D3, 1999-2009. 
HOSKING J.R.M., WALLIS J.R., 1997: Regional frequency analysis: an approach based on L-moments. Cambridge University Press, Cambridge, $224 \mathrm{pp}$.

HUBERT P., BENDJOUDI H., SCHERTZER D., LOVEJOY S., 2002: Multifractal taming of extreme hydrometerological events. In: The Extremes of the Extremes (Proceedings of Reykjavik Symposium, July 2000). IAHS Publication, No. 271, 51-56.

JAVELLE P., GRÉSILLON J.M., GALEA G., 1999: Discharge-duration-frequency curve modeling for floods and scale invariance. C. R. Acad. Sci. Paris, Earth and Planetary Sciences, 329, 39-44.

KOUTSOYIANNIS D., FOUFOULA-GEORGIU E., 1993: A scaling model of a storm hyetograph. Water Resources Research, 29, 7, 2345-2361.

KOUTSOYIANNIS D., KOZONIS D., MANETAS A., 1998: A mathematical framework for studying rainfall intensityduration-frequency relationships. Journal of Hydrology, 206, 118-135.

LANGBEIN W.B., 1949: Annual maximum series and the partial-duration series. Transactions, Amer. Geophys. Union, 30, 6, 879-881.

LAPIN M., MELO M., 2004: Methods of climate change scenarios projection in Slovakia and selected results. Journal of Hydrology and Hydromechanics, 52, 4, 224-238.

LAPIN M., MELO M., 2005: Priestorová interpretácia výstupov klimatických scenárov v povodí Hrona a Váhu geoštatistickými metódami. (Spatial interpretation of climate scenario outputs in catchments of the Hron and Váh Rivers by means of geostatistical methods.) (In Slovak.) In Pekárová P. et al. (eds.), 2005: Scenáre zmien vybraných zložiek hydrosféry a biosféry v povodí Hrona a Váhu v dôsledku klimatickej zmeny. (Scenarios of selected components of the hydrosphere and biosphere in catchments of the Hron and Váh Rivers due to climatic change.) VEDA, Bratislava, 49-80.

LOVEJOY S., SCHERTZER D., 1985: Generalized scale invariance and fractal models of rain. Water Resources Research, 21, 8, 1233-1250.

MARANI M., 2005: Non-power-law-scale properties of rainfall in space and time. Water Resources Research, 41, W08413, doi:10.1029/2004WR003822.

MARIEN J.L., VANDEWIELE G.L., 1986: A point rainfall generator with internal storm structure. Water Resources Research, 22, 4, 5231-5238.

MENABDE M., SEED A., PEGRAM G., 1999: A simple scaling model for extreme rainfall. Water Resources Research, 35, 1, 335-339.

MINH NHAT L., TACHIKAWA Y., SAYAMA T., TAKARA K., 2007: Regional rainfall intensity-duration-frequency relationships for ungauged catchments based on scaling properties. Annuals of Disas. Prev. Res. Inst., Kyoto Univ., No 50B.

MOLNAR P., BURLANDO P., 2008: Variability in the scale properties of high-resolution precipitation data in the Alpine climate of Switzerland. Water Resources Research, 44, W10404, doi:10.1029/2007WR006142.

PEKÁROVÁ P., ONDERKA M., PEKÁR J., MIKLÁNEK P., HALMOVÁ D., ŠKODA P., BAČOVÁ MITKOVÁ V., 2008: Hydrologic scenarios for the Danube River at Bratislava. ISBN 978-80-87071-51-9, Ostrava, KEY Publishing, $152 \mathrm{p}$.

PEKÁROVÁ P., 2009: Flood regime of rivers in the Danube River basin. J. Hydrol. Hydromech., 57, 2, 142-143.
RODRIGUEZ-ITURBE I., GUPTA V.K., WAYMIRE E.C., 1984: Scale considerations in the modeling of temporal rainfall. Water Resources Research, 20, 11, 1611-1619.

ROSSO R., BURLANDO P., 1990: Scale invariance in temporal and spatial rainfall. In: Proceedings of the 15th General Assembly of the European Geophysical Society, 23-27 April, 1990, Copenhagen. Annales Geophysicae, 145 (abstract).

ŠAMAJ F., VALOVIČ Š., 1973: Intenzity krátkodobých dažd'ov na Slovensku. (Short-term rainfall intensities in Slovakia.) (In Slovak.) Proceedings of the Slovak Hydrometeorological Institute, Vol. 5, SPN Bratislava.

SIVAPALAN M., WOOD E.F., 1987: A multidimensional model of nonstationarity space-time rainfall at the catchment scale. Water Resources Research, 23, 7, 1289-1299.

SMITH J.A., 1992: Representation of basin scale in flood peak distributions. Water Resources Research, 28, 11, 2993$-2999$.

SZOLGAY J., KOHNOVÁ S., HLAVČOVÁ K., MINÁRIK M., 2007: K používaniu Langbeinovho vzorca pre dobu opakovania $\mathrm{v}$ hodnotení povodňového rizika. (To the use of the Langbein formula by the assessment of flood risk.) (In Slovak.) In Čejp J., Julíne T., Ríha J. (eds.): Rizika ve vodním hospodáŕství. Brno, ECON, 494-499.

URCIKÁN P., IMRIŠKA L., 1986: Stokovanie a čistenie odpadových vôd. Tabul'ky na výpočet stôk. (Sewage and wastewater treatment. Tables for sewage system design.) (In Slovak.) ALFA-SNTL Bratislava.

VENEZIANO D., FURCOLO P., 2002: Multifractality of rainfall and scaling of intensity-duration-frequency curves. Water Resources Research, 38, 12, 1306, doi: 10.1029/2001WR000372.

VENEZIANO D., BRAS R.L., NIEMANN J.D., 1996: Nonlinearity and self-similarity of rainfall in time and a stochastic model. Journal of Geophysical Research, 101, D21, 26,371$-26,392$.

VENEZIANO D., LEPORE CH., LANGOUSIS A., FURCOLO P., 2007: Marginal methods of IDF estimation in scaling and non-scaling rainfall. Water Resources Research., 43, 10, W10418.

WAYMIRE E.C., GUPTA V.K., 1981: The mathematical structure of rainfall representation. 1. A review of stochastic rainfall models, 2. A review of the point processes theory, 3 . Some applications of the point process theory to rainfall processes. Water Resources Research, 17, 5, 1261-1294.

WAYMIRE E.C., GUPTA V.K., RODRIGUEZ-ITURBE I., 1984: A spectral theory of rainfall intensity at the meso- $\beta$ scale. Water Resources Research, 20, 10, 1453-1465.

WILLEMS P., 2000: Compound intensity/duration/frequencyrelationships of extreme precipitation for two seasons and two storm types. Journal of Hydrology, 233, 1-4, 189-205.

YU P.-S., YANG T.-C., LIN C.-S., 2004: Regional rainfall intensity formulas based on scaling property of rainfall. Journal of Hydrology, 295, 1-4, 108-123.

Received 9. June 2009 Accepted 14. October 2009 
VYUŽITIE METÓDY JEDNODUCHÉHO

ŠKÁLOVANIA EXTRÉMNYCH ZRÁŽOK

PRI REGIONÁLNOM ODHADE NÁVRHOVÝCH DAŽĎOV NA SLOVENSKU

Márta Bara, Ladislav Gaál, Silvia Kohnová, Ján Szolgay, Kamila Hlavčová

Určenie návrhových intenzít zrážok je jedným zo základných nástrojov pri plánovaní a navrhovaní $\mathrm{v}$ inžinierskej hydrológii a vodohospodárstve, napr. pri protipovodňovej ochrane alebo dimenzovaní vodohospodárskych objektov. Prvé práce venované problematike návrhových dažd'ov na Slovensku vznikali v druhej polovici 20. storočia. Dub (1950) zostrojil prvú obalovú krivku návrhových intenzít dažd’ov pre Slovensko. Šamaj, Valovič (1973) určili návrhové hodnoty dažd'ov pre 68 zrážkomerných staníc na Slovensku, ich výsledky neskôr Urcikán a Horváth (Urcikán, Imriška, 1986) prepracovali a uviedli metódu na určenie návrhových hodnôt aj pre miesta bez priamych pozorovaní. Tieto práce stále slúžia ako podklad pre inžiniersku prax, avšak v súčasnosti už nespĺn̆ajú nároky na matematické pozadie analýzy zrážok. V posledných rokoch bola vo svete venovaná zvýšená pozornost' rozdeleniu zrážok v priestore a čase, napr. Waymire, Gupta (1981), Rodriguez-Iturbe et al. (1984), Marien, Vandewiele (1986), Sivapalan, Wood (1987). Analyzovali sa škálovacie vlastnosti zrážok a vznikali rôzne modely škálovania, napr. Gupta, Waymire (1990), Koutsoyiannis, FoufoulaGeorgiu (1993), Veneziano et al. (1996; 2007), Molnar, Burlando (2008). Model jednoduchého škálovania aplikovali na zrážkové intenzity napr. Menabde et al. (1999) a $Y u$ et al. (2004). Táto metóda umožňuje určit' návrhové hodnoty zrážok pre l'ubovol'né trvanie a zvolené periodicity využitím odvodených charakteristík napr. jednodenných úhrnov zrážok, ktorých dostupnost' je neporovnatel'ne lepšia než dostupnost' ombrografických záznamov.

$\mathrm{V}$ našej práci sme aplikovali metódu jednoduchého škálovania a overili sme možnost' využitia regionálneho škálovacieho koeficientu na odhad návrhových zrážkových intenzít pre miesta bez priamych pozorovaní.

$\mathrm{Na}$ základe výsledkov regionalizácie jednodenných maximálnych úhrnov zrážok v práci Gaál (2006) bolo pre analýzu vybraných 19 zrážkomerných staníc vo vopred vyčlenenom regióne na území západného Slovenska (obr. 1). Vstupné údaje tvorili návrhové zrážkové intenzity trvania 5 až 180 minút určené autormi Šamaj, Valovič (1973), doplnené o denné údaje zrážkových úhrnov (podrobný opis spracovania vstupných údajov pozri napr. v Bara et al., 2008). Počet rokov pozorovaní $\mathrm{v}$ jednotlivých staniciach je uvedený $\mathrm{v}$ tab. 1 . $Z$ celkového počtu analyzovaných staníc sme vyčlenili 3 verifikačné stanice: Kuchyňa-Nový Dvor, Nitrianske Pravno a Čadca.

Pre vybraný región sme odvodili bezrozmernú regionálnu čiaru prekročenia jednodenných maximálnych úhrnov zrážok v teplom polroku a následne sa vo verifikačných staniciach metódou indexovej hodnoty (Hosking, Wallis, 1997) odhadli lokálne návrhové hodnoty pre rôzne významné doby opakovania $T$ (tzv. $T$-ročné kvantily).

Následne sme pre analyzovanú oblast' určili priemerný regionálny škálovací exponent, ktorého hodnota bola 0,7321 . Pre verifikačné stanice sa pomocou škálovacieho exponentu metódou jednoduchého škálovania určili návrhové zrážkové intenzity s trvaním $5,10,15,20,30$, 40, 50, 60, 90, 120 a 180 minút, zoškálovaním kvantilov jednodenných zrážkových úhrnov určených regionálnym prístupom. Výsledky sa porovnali s návrhovými hodnotami, ktoré určili Šamaj, Valovič (1973) pre tieto lokality. Na obr. 3-5 je zobrazený rozdiel medzi návrhovými hodnotami stanovenými pomocou regionálneho škálovacieho koeficientu a určenými autormi Šamaj, Valovič (1973) pre tri verifikačné stanice.

Výsledky ukázali, že oproti návrhovým hodnotám, ktoré boli odvodené autormi Šamaj, Valovič (1973), návrhové hodnoty určené metódou jednoduchého škálovania v prípade regionálneho aj lokálneho prístupu sú vo všeobecnosti podhodnotené ( $\mathrm{v}$ priemere asi o 15\%). Najväčšie rozdiely sa pozorovali pri zrážkových oddieloch kratšieho trvania, čo môže značit', že hypotéza jednoduchého škálovania nie je ideálna a treba uvážit' použitie modelu mnohonásobného škálovania zrážok (napr. Veneziano, Furcolo, 2002).

Táto štúdia overila možnosti využitia metód škálovania pri odhade návrhových hodnôt krátkodobých intenzít zrážok na Slovensku. 